\title{
Nitrogen soil surface budgets for districts in Germany 1995 to 2017
}

\author{
Uwe Häußermann ${ }^{1 *}$ (1), Laura Klement ${ }^{1}$, Lutz Breuer ${ }^{1,2}$, Antje Ullrich ${ }^{3}$, Gabriele Wechsung ${ }^{3}$ and Martin Bach ${ }^{1}$
}

\begin{abstract}
Background: Nitrogen (N) as a key input for crop production has adverse effects on the environment through emissions of reactive nitrogen. Less than $20 \%$ of the fertiliser nitrogen applied to agricultural land is actually consumed by humans in meat. Given this situation, nitrogen budgets have been introduced to quantify potential losses into the environment, to raise awareness in nutrient management, and to enforce and monitor nutrient mitigation measures. The surplus of the $\mathrm{N}$ soil surface budget has been used for many years for the assessment of potentially water pollution with nitrate from agriculture.

Results: For the 402 districts in Germany, nitrogen soil surface budgets were calculated for the time series 1995 to 2017. For the first time, biogas production in agriculture and the transfer of manure between districts were included in the budget. Averaged for all districts, the recent $\mathrm{N}$ supply to the utilised agricultural area (UAA) totals $227 \mathrm{~kg} \mathrm{~N} \mathrm{ha}^{-1}$ UAA (mean 2015-2017), among them $104 \mathrm{~kg} \mathrm{~N} \mathrm{ha}^{-1}$ UAA mineral fertiliser, $59 \mathrm{~kg} \mathrm{~N} \mathrm{ha}^{-1}$ UAA manure, $33 \mathrm{~kg} \mathrm{~N} \mathrm{ha}^{-1}$ UAA digestate, $14 \mathrm{~kg} \mathrm{~N} \mathrm{ha}^{-1}$ UAA from gross atmospheric deposition, $13 \mathrm{~kg} \mathrm{~N} \mathrm{ha}^{-1}$ UAA biological $\mathrm{N}$ fixation, and $1 \mathrm{~kg} \mathrm{~N} \mathrm{ha}^{-1}$ UAA from seed and planting material. The withdrawal with harvested products accounts for $149 \mathrm{~kg} \mathrm{~N}$ $\mathrm{ha}^{-1} \mathrm{UAA}$, resulting in an $\mathrm{N}$ soil surface budget surplus of $77 \mathrm{~kg} \mathrm{~N} \mathrm{ha}^{-1} \mathrm{UAA}$. The $\mathrm{N}$ surpluses per district (mean 2015-2017) vary considerably between 26 and $162 \mathrm{~kg} \mathrm{~N} \mathrm{ha}^{-1}$ UAA and the nitrogen use efficiency of crop production ranges from 0.53 to 0.79 in the districts. The $\mathrm{N}$ surplus in Germany as a whole has remained nearly constant since 1995, but the regional distribution has changed significantly. The N surplus has decreased in the arable farming regions, but increased in the districts with high livestock density. Some of this surplus, however, is relocated to other districts through the transfer of manure.

Conclusions: The 23-year time series forms a reliable basis for further interpretation of $\mathrm{N}$ soil surface surplus in Germany. Agri-environmental programmes such as the limitation of the N surplus through the Fertiliser Ordinance and the promotion of biogas production have a clear effect on the $\mathrm{N}$ surplus in Germany as a whole and its regional distribution.
\end{abstract}

Keywords: Agriculture, Biogas, Germany, Nitrogen soil surface budget, Nitrogen use efficiency, NUTS 3

\section{Background}

Nitrogen $(\mathrm{N})$ is a key input for crop production, but has adverse effects on the environment through the emissions of reactive N. Since the development of the Haber-Bosch process for technical ammonia synthesis

\footnotetext{
*Correspondence: uwe.haeussermann@umwelt.uni-giessen.de ${ }^{1}$ Institute for Landscape Ecology and Resources Management, Research Centre for BioSystems, Land Use and Nutrition (iFZ), Justus Liebig University Giessen, Heinrich-Buff-Ring 26, 35392 Giessen, Germany Full list of author information is available at the end of the article
}

around a century ago, humans have intervened in the $\mathrm{N}$ cycle more than in any other geochemical elemental cycle [1]. The production of $\mathrm{N}$ fertilisers on an industrial scale strongly increased global agricultural productivity in most regions of the world [2]. However, a large proportion of this $\mathrm{N}$ is lost to the environment: on the global scale less than $20 \%$ of the fertiliser $\mathrm{N}$ applied to agricultural land is actually consumed by humans in meat, but over $80 \%$ is lost to the environment, much of it into the air and into rivers, groundwater and coastal
Springer Open

(C) The Author(s) 2020. This article is licensed under a Creative Commons Attribution 4.0 International License, which permits use, sharing, adaptation, distribution and reproduction in any medium or format, as long as you give appropriate credit to the original author(s) and the source, provide a link to the Creative Commons licence, and indicate if changes were made. The images or other third party material in this article are included in the article's Creative Commons licence, unless indicated otherwise in a credit line to the material. If material is not included in the article's Creative Commons licence and your intended use is not permitted by statutory regulation or exceeds the permitted use, you will need to obtain permission directly from the copyright holder. To view a copy of this licence, visit http://creativeco mmons.org/licenses/by/4.0/. 
seas $[3,4]$. Thus, it is a big challenge to produce enough food for the growing global population while at the same time minimising the emission of reactive $\mathrm{N}$ to the environment.

Given this situation, agriculture $\mathrm{N}$ budgets have been introduced to clarify the nutrient flows, to quantify the potential $\mathrm{N}$ losses, to indicate the pressure on environmental media, to raise awareness in nutrient management, and to enforce and monitor nutrient mitigation regulations in practice [5]. For example, "Gross nitrogen balance" and "Mineral fertiliser consumption" are two (of 28) agri-environmental indicators used by EUROSTAT and the European Environmental Agency to evaluate agricultural impact on the environment and to monitor the effects of agri-policy measures in the EU [6]. The European Environment Agency [7] regarded the surplus of $\mathrm{N}$ as the best overall environmental indicator for the changes in the agricultural impact on the environment. De Vries et al. [8] also stated that $\mathrm{N}$ budgets of agricultural systems give important information for assessing the impact of $\mathrm{N}$ inputs on the environment, and for identifying levers for action. Since the 1990s, agriculture in Western Europe has managed to reduce its $\mathrm{N}$ surpluses, due to national and EU policies. The reduction in $\mathrm{N}$ budget surplus and in groundwater nitrate concentration in Denmark illustrates the success that can be achieved if effective measures are taken [9].

The literature offers numerous methods, definitions of system boundaries and calculation schemes to estimate an $\mathrm{N}$ budget surplus. According to the Eurostat/ OECD Nutrient Budget Handbook [10], an N budget quantifies all major $\mathrm{N}$ flows across all sectors and media within given boundaries, and flows across these boundaries, within a given time frame (typically one year), as well as the changes of $\mathrm{N}$ stocks in the relevant sectors and media. An $\mathrm{N}$ balance is ideally a closed $\mathrm{N}$ budget, i.e. all $\mathrm{N}$ flows can be explained and the balance equation is then [10]:

$$
N(\text { input })-N(\text { output }) \pm N(\text { stock change })=0 .(1)
$$

In practice, however, essential flows of an $\mathrm{N}$ balance such as gaseous losses, nitrate leaching and soil stock changes cannot be determined. Therefore, the $\mathrm{N}$ budget surplus, as given by total inputs minus total outputs, represents the $\mathrm{N}$ quantity which is volatilised to the air, leached to groundwater, discharged to surface water, or stored in the soil. Therefore, an $\mathrm{N}$ budget surplus value includes all $\mathrm{N}$ components emitted into the environment or accumulated in the organic soil substance.

According to the objective and the system boundary there are basically three approaches to estimate nutrient budgets [8, 10, 11]: (i) farm budget (called farm-gate budget by Oenema et al. [5]), which records the amounts of $\mathrm{N}$ in all kinds of products that enter and leave the farm via the farm-gate; the equivalent on the national scale is the agricultural system budget, also termed sector balance [12]; (ii) Land budget (gross $N$ balances by the OECD [13]), which records all $\mathrm{N}$ that enters a farmland and leaves the farmland by crop products; and (iii) Soil budget (soil surface budget by Oenema et al. [5]), where in contrast to the land $\mathrm{N}$ budget, the $\mathrm{N}$ inputs via animal manure are adjusted for gaseous losses of $\mathrm{N}$ emissions in housing and manure management systems. The latter budget is estimated in this work. Due to the lack of an exact definition of the terms $N$ balance and $N$ budget as it is described here, in older studies these terms are not always used consistently.

While the $\mathrm{N}$ budget surplus indicates the potential for $\mathrm{N}$ losses from soils into the atmosphere and the hydrosphere quantitatively, the Nitrogen Use Efficiency (NUE), or $\mathrm{N}$ recovery efficiency as termed by Conant et al. [14], evaluates the efficiency of the use of the resource $\mathrm{N}$ in crop production [11].

Over the last three decades, a huge number of agricultural $\mathrm{N}$ budgets and $\mathrm{N}$ balances have been presented. The approaches differ by many issues such as system boundaries, geographical entities, budget period, input and output budget terms, data sources, as well as factors and coefficients used for calculation. With regard to the regional focus of the $\mathrm{N}$ budget presented in our study, the following examples highlight the manifold approaches of spatialised $\mathrm{N}$ budgets and differences in employed data basis. Eriksson et al. [15] drew up N budgets of Polish agriculture 1960-2000 based on the administrative units of voivodeships (provinces). The regional $\mathrm{N}$ surpluses for the ten Danish geo-regions were derived by Hansen et al. [9]. Grizzetti et al. [16] produced EU-15 maps of spatialised inputs from agriculture and gross $\mathrm{N}$ balance by combining the EU Farm Structure Survey 2000 data with the CORINE Land Cover map. Wang et al. [17] estimated N balances for 2426 counties in China from statistical survey data.

Leip et al. [11] calculated soil $\mathrm{N}$ budgets for agriculture in the EU-27 using the agro-economic model CAPRI. Özbek et al. [18] assessed N budgets of agriculture in Turkey at the level of 27 NUTS 2 regions by an improved Eurostat/OECD method. Lassaletta et al. [19] calculated $\mathrm{N}$ budgets for the river Ebro catchment detailed for territorial units derived by overlaying maps of main agricultural use, livestock density, and hydrographic characteristics. Bach et al. [20] assessed agricultural nutrient balances from agricultural census data exemplary for 1109 municipalities of Baden-Wuerttemberg (Germany). A comparison of N budgets for the year 2000 
of agro-ecosystems is made for the EU-27 countries by four models with different complexity and data requirements [8, 21]: The IDEAg model uses 206,000 HSMUs (Homogeneous Spatial Mapping Units), while the INTEGRATOR model operates for 39,052 NCUs (NitroEurope Calculation Units, clusters of $1-\mathrm{km}^{2}$ grid cells that are characterised by similar environmental and agronomic conditions). While the total $\mathrm{N}$ surplus on the EU level is similar between the four models, the difference in $\mathrm{N}$ output fluxes between models is large on a regional scale.

The $\mathrm{N}$ soil surface budget surplus is applied in particular as a core indicator for assessing the nitrate input into groundwater and surface waters from agricultural land use. The Nitrate Atlas for Germany [22] presented one of the first such model approaches, using the $\mathrm{N}$ surplus of the utilised agricultural area (UAA) for $3 \mathrm{~km} \times 3 \mathrm{~km}$ grids. Campling et al. [23] implemented spatialised soil surface $\mathrm{N}$ balances as pressure indicator for river basins in the EU-15 using the CORINE Land Cover map. The MITERRA-EUROPE model assesses the agricultural $\mathrm{N}$ balances and the loss of reactive $\mathrm{N}$ species to the environment for the EU Member States for the 234 NUTS 2 regions [24]. Bouraoui and Grizzetti [25] reviewed some of the models applied in Europe to assess the contribution of diffuse $\mathrm{N}$ water pollution and the effectiveness of mitigation measures. The risk of water contamination was modelled for the 3500 polygons of the 1:1,000,000 Map of Soil Landscapes of Canada by calculating the "residual soil nitrogen" (RSN) [26]. Howarth et al. [27] introduced the quantity "net anthropogenic nitrogen input" (NANI) as a well-correlated measure of $\mathrm{N}$ transported in rivers, which was also used by Lassaletta et al. [19] for the river Ebro catchment (Spain).

The listed publications illustrate the huge diversity of the spatial resolution and underlying data basis of approaches introduced to calculate an N budget. Given the heterogeneity of definitions, approaches and methods, it is not surprising that the results of $\mathrm{N}$ budgets from forms a core indicator for evaluating the sustainability of agriculture in Germany [28]. The EU Water Framework Directive calls on all Member States to submit an inventory of nutrient emissions and river loads for their river basins. In Germany, the river basin management models MONERIS [29] and MoRE [30] are frequently applied for Germany to estimate $\mathrm{N}$ emissions into water bodies from various sources and to prioritise measures to reduce $\mathrm{N}$ losses into the hydrosphere. In both models, the $\mathrm{N}$ soil surface surplus of agricultural land is a core quantity to evaluate the spatial risk of nitrate losses into groundwater. For this purpose, the model MoRE calculates the $\mathrm{N}$ soil surface surplus for districts [31], while the model MONERIS involves the $\mathrm{N}$ input and output on the community level for Germany by the RAUMIS approach [32].

We present the methodology and the results of $\mathrm{N}$ soil surface budget calculation for the district administrative units (Nomenclature des unités territoriales statistiques, NUTS 3 level, "Kreise") in Germany for the time series 1995 to 2017. To our knowledge, it is the first time that the $\mathrm{N}$ surplus for a territory is determined for a time series of more than 20 years with such high spatial resolution. We use the data to focus on five aspects: the status and trend of nitrogen input and budget surplus in German agriculture, the contribution of biogas production to the $\mathrm{N}$ budget surplus, the regional spread of $\mathrm{N}$ budget surplus and NUE, the change in regional nitrogen budget surplus, and finally the potential effect of the German Fertiliser Ordinance [33] on the regional distribution of the $\mathrm{N}$ surpluses.

\section{Materials and methods}

In general, nutrient budgets can be established for each agricultural production system: crop production, livestock production, and biogas (energy) generation. The latter has gained increasingly relevance in German agriculture since the Renewable Energy Sources Act was revised in 2004. The $\mathrm{N}$ budget surpluses are linked as follows:

Agricultural system budget surplus = soil surface budget surplus + livestock budget surplus + biogas budget surplus

various studies may differ substantially and can only be compared with great limitations or not at all. $\mathrm{N}$ surplus data should therefore be interpreted less in terms of its absolute value than in terms of its change over time and/ or its spatial dispersion within a region. As an example, the German Federal Government construes the trend in national $\mathrm{N}$ surplus as evidence of the effectiveness of the measures taken to reduce groundwater nitrate pollution, and reports these every 4 years to the EU Commission on the implementation of the EU Nitrates Directive. The $\mathrm{N}$ surplus of Germany's agricultural $\mathrm{N}$ budget also
Table 1 presents the $\mathrm{N}$ budget terms for the individual budgets and their allocation in the overall $\mathrm{N}$ budget sheet. For $\mathrm{N}$ budgets below the national level, i.e. for federal states, districts or municipalities, only $\mathrm{N}$ soil surface budgets can be determined due to limited data availability in Germany. The methodology and the input and output terms differ in some details from the calculation scheme for the $\mathrm{N}$ soil budget according to the OECD [12, 13] especially with regard to the biogas component. The NUE is finally calculated as the ratio of total output with harvest withdrawal to total input. 
Table 1 Scheme of the $\mathbf{N}$ agricultural system (sectoral) budget and the linking between its components soil surface budget, livestock budget and biogas budget

\begin{tabular}{|c|c|c|c|c|}
\hline Budget term ${ }^{a, b}$ & $\begin{array}{l}\text { Agricultural } \\
\text { system budget }\end{array}$ & $\begin{array}{l}\text { Soil surface } \\
\text { budget }^{\mathrm{b}}\end{array}$ & $\begin{array}{l}\text { Livestock } \\
\text { budget }\end{array}$ & Biogas budget \\
\hline \multicolumn{5}{|l|}{ Input } \\
\hline Mineral fertiliser (inorganic fertiliser) & + & $+^{\mathrm{b}}$ & & \\
\hline Manure, transfer (import) from other regional entities (federal states, districts, abroad) & + & $+^{\mathrm{b}}$ & & \\
\hline Compost, sewage sludge, meat-and-bone meal & + & $+^{b}$ & & \\
\hline Feed from domestic industrial production & + & & + & \\
\hline Feed import (from other regional entities or abroad) & + & & + & \\
\hline Biological N fixation & + & $+{ }^{\mathrm{b}}$ & & \\
\hline Biogas co-substrates (biowaste, non-agricultural origin) & + & & & + \\
\hline Seeds and planting material & + & $+^{\mathrm{b}}$ & & \\
\hline Atmospheric $\mathrm{NO}_{x}$ deposition on UAA & + & $+{ }^{b}$ & & \\
\hline \multicolumn{5}{|l|}{ Internal flows (with respect to the sectoral budget) } \\
\hline Manure (on-farm production) for use as fertiliser & & $+{ }^{b}$ & - & \\
\hline Animal manure (on-farm production) for use as substrate in biogas plants & & & - & + \\
\hline Harvest withdrawal of fodder crops (on-farm use in livestock production) & & $-{ }^{b}$ & + & \\
\hline Harvest withdrawal of energy plants for biogas & & $-{ }^{b}$ & & + \\
\hline Digestate from biogas plants & & $+{ }^{b}$ & & - \\
\hline $\mathrm{NH}_{3}$ emission which returns as deposition on UAA & & & $-{ }^{b}$ & $-{ }^{b}$ \\
\hline Atmospheric net $\mathrm{NH}_{3}$ deposition on UAA & & $+^{\mathrm{b}}$ & & \\
\hline \multicolumn{5}{|l|}{ Output } \\
\hline Harvest withdrawal of marketed crops & - & - & & \\
\hline Marketed animal products & - & & - & \\
\hline Animal manure, transfer to other regional entities & - & & - & \\
\hline Digestate, transfer to other regional entities & - & & & - \\
\hline Budget surplus & Sum & Sum & Sum & Sum \\
\hline
\end{tabular}

+: Supply, budget term is added; -: withdrawal, budget term is subtracted

a The naming of the budget terms refers to the regional budget for districts, the naming may differ for budgets for other spatial units (e.g. Germany as a whole, farms or fields). Allocation of terms as input, internal flow and output is made with respect to the sectoral budget

b Terms of the $\mathrm{N}$ soil surface budget

\section{Data base}

Most of the data required to calculate the input, internal flow and output of $\mathrm{N}$ in agricultural production (e.g. cropping acreages, livestock numbers, and mineral fertiliser sales) are provided by the Federal Statistical Office (www.destatis.de). Over the past two decades, complete Farm Structure Surveys (FSS) covering all or a representative sample of agricultural holdings are available for 1995, 1996, 1999, 2001, 2003, 2007, 2010, 2013, and 2016. Full data sets on UAA, arable land by crop types and livestock numbers for districts are limited to the years with a FSS. For budget calculation of interim years, the figures for the districts were interpolated based on annual updates for the federal states. Data on harvest yields of most field crops are reported annually for districts. Coefficients of $\mathrm{N}$ contents in harvested crops and leguminous $\mathrm{N}$ fixation rates are taken from the German Fertiliser Ordinance [33]. Livestock $\mathrm{N}$ excretion rates, $\mathrm{N}$ input with bedding and gaseous $\mathrm{N}$ losses from manure management (housing and storage) (partial $\mathrm{N}$ emission factors) for the calculation of the $\mathrm{N}$ supply with manure are provided by the German Greenhouse Gas Emissions Inventory [34] as annual and district-specific values for livestock categories. Sources of statistical data and $\mathrm{N}$ coefficients as well as the budget calculation methodology are documented in detail in Additional file 1.

\section{Mineral fertiliser input}

Reliable statistical data on mineral fertiliser sales are published only for Germany as a whole and therefore estimates have to be made for regional $\mathrm{N}$ budgets entities. Assessing the appropriate mineral fertilising quantity is a major problem in $\mathrm{N}$ balancing of districts and the most sensitive factor of regional $\mathrm{N}$ surplus estimations. In our approach the amount of mineral fertiliser for districts are derived from the national total. The approach attempts to stimulate the farmer's $\mathrm{N}$ management planning in a simplified way and starts with the $\mathrm{N}$ demand of the cultivated 
crops. Crop $\mathrm{N}$ demand is determined from the $\mathrm{N}$ harvest withdrawal multiplied by a fertiliser input factor (IF) to allow for the fact that regularly more $\mathrm{N}$ is applied with inorganic and organic fertilisers and legume $\mathrm{N}$ fixation than the $\mathrm{N}$ harvest withdrawal in Germany corresponds to. The crop $\mathrm{N}$ demand is met by mineral fertilisers (min fert), on-farm organic $\mathrm{N}$ fertilisers (org_fert, i.e. liquid manure, solid manure, digestate) and biological $\mathrm{N}$ fixation by legumes (fix). However, only a proportion of $\mathrm{N}$ in organic fertilisers and from biological $\mathrm{N}$ fixation is available for plant nutrition and thus effective for fertilising, which respect the utilisation factors (UF): livestock units by the $\mathrm{N}$ excretion rate per animal place and year, for dairy cows the $\mathrm{N}$ excretion is a function of the annual milk yield. Thereof the gaseous $\mathrm{N}$ losses during livestock housing and manure storage are subtracted (separately for ammonia and for the other gaseous $\mathrm{N}$ species), whereas gaseous $\mathrm{N}$ losses from manure spreading on the field are not subtracted, to get the $\mathrm{N}$ input with manure to the $\mathrm{N}$ soil surface budget.

Since 2013, the federal states with highest regional concentration of livestock production (North Rhine-Westphalia, Lower Saxony, and Schleswig-Holstein) report the nutrient transfer within the districts of the federal

$$
\mathrm{N}(\text { tot_fert })=\mathrm{N}(\text { harvest }) \times \mathrm{IF}=\mathrm{N}(\text { min_fert })+\mathrm{N}(\text { org_fert }) \times \mathrm{UF} 1+\mathrm{N}(\text { fix }) \times \mathrm{UF} 2 \text {. }
$$

Other organic $\mathrm{N}$ fertilisers (biowaste compost, sewage sludge, meat-and-bone meal) are not taken into account in Eq. (3), because the $\mathrm{N}$ supply with these substances is generally very low (on the national level) and the $\mathrm{N}$ is only slowly released, so that the contribution of these $\mathrm{N}$ sources to the current plant $\mathrm{N}$ supply is negligible. Due to the broad variability of real data, in the following UF1 is set as conservative assumption to 0.6 and UF2 to 0.8 . This means, $40 \%$ and $20 \%$, respectively, of the $\mathrm{N}$ from animal manure and biological $\mathrm{N}$ fixation are not taken into account into the $\mathrm{N}$ demand analysis according to the German Fertiliser Ordinance [33]. On the national level the annual values of the variables $\mathrm{N}$ (min_fert), $\mathrm{N}$ (harvest), $\mathrm{N}$ (org_fert) and $\mathrm{N}$ (fix) are given and then IF was calculated by Eq. (3) for each year of the time series 1995 to 2017, ranging from 0.98 to 1.35 with a mean value of 1.13 . For details of the derivation of UF1, UF2 and IF, see Section 2.4.1 in Additional file 1.

Subsequently, for district $\mathrm{N}$ budgets the individual district mineral $\mathrm{N}$ fertilising as target value was calculated as remaining fertilising quantity after a share of the district total $\mathrm{N}$ needs are met with organic $\mathrm{N}$ fertilisers and biological $\mathrm{N}$ fixation, calculated from the livestock numbers and the legume cropping area of the given district: state, between federal states and between these states and foreign countries. The import of manure from the Netherlands to Germany was assessed based on data of the Statistical Office of the Netherlands in combination with the nutrient reports of North Rhine-Westphalia and Lower Saxony.

\section{Biogas digestate input}

The German Federal Network Agency, the four German power transmission system operators and the German Energy Agency (Dena) provide inventory data on the location of biogas plants and their electric energy $\left(G W_{e l}\right)$ annually fed into the grid (for plants with on-site power generation) or their methane volume $\left(\mathrm{Mm}^{3}\right)$ annually fed into the natural gas grid (for biomethane feed-in plants). Mean composition of the used biogas substrates (separately for six biomass plants, manure, and co-substrates) are taken from a national review of biogas activity data [35]. Substrate quantities are derived from the specific biogas yield of the substrates resulting in coefficients of the substrate $\mathrm{N}$ input per $\mathrm{GWh}_{\mathrm{el}}$ of electric energy fedin (equivalent per $\mathrm{Mm}^{3}$ biomethane fed-in) for energy crops, manure and biowaste. The $\mathrm{N}$ input to crop production with the application of digestates is then taken as

$$
\mathrm{N}(\text { min_fert })=\mathrm{N}(\text { harvest }) \times \mathrm{IF}-\mathrm{N}(\text { org_fert }) \times \mathrm{UF} 1-\mathrm{N}(\text { fix }) \times \mathrm{UF} 2 .
$$

The variables on the right-hand side of Eq. (4) are known for each district (see below), the parameters IF, UF1 and UF2 were kept identical for all districts. This approach ensures that the amount of N(min_fert) summed over all districts is equal to the national total of mineral fertiliser sales.

\section{Manure input (on-farm production and transfer)}

The $\mathrm{N}$ amount in liquid and solid manure from livestock farming is calculated by multiplying the number of
$\mathrm{N}$ input with substrates into the biogas plants minus the overall gaseous $\mathrm{N}$ emissions in the biogas process chain according to [34]. The contribution of biogas production to the $\mathrm{N}$ soil surface budget surplus (Fig. 2) was calculated based on the assumption that each $\mathrm{N}$ input source contributes to the $\mathrm{N}$ soil surface budget surplus according to their respective share from the total $\mathrm{N}$ input into the soil. 


\section{Other organic fertiliser input}

Other organic fertilisers include compost from urban green waste, sewage sludge and meat-and-bone meal for use as fertiliser or soil amelioration. Only national data are available on compost and meat-and-bone meal use in agriculture; sewage sludge statistics are published for the federal states. The $\mathrm{N}$ quantity of these fertilisers is generally very low, thus the authors consider the error resulting from the even distribution over the UAA of all districts as acceptable.

\section{Biological $N$ fixation}

The amount of $\mathrm{N}$ fixed by symbiotic bacteria in the soil is calculated as the acreage of legumes (pulses, clover, alfalfa and grass-legume mixtures) multiplied by the crop-specific $\mathrm{N}$ fixation rates [33].

\section{Seeds and planting material input}

Input with seeds of coarse grains (cereals, maize, and legumes) and potato planting material is accounted [33].

\section{Atmospheric $\mathrm{N}$ deposition}

$\mathrm{N}$ input with atmospheric deposition is derived from the PINETI-3 project (Pollutant INput and EcosysTem Impact) modelling the annual total deposition of $\mathrm{NO}_{\mathrm{x}}$ and $\mathrm{NH}_{\mathrm{y}}$ in Germany with $1 \mathrm{~km} \mathrm{x} 1 \mathrm{~km}$ resolution for ten vegetation classes, from 2000 to 2015 [36]. PINETI-3 grid maps were superimposed with a land cover model of Germany and for each grid cell the fractions for the vegetation classes "arable land" and "grassland" were determined. Then this map was superimposed on the administrative boundary map and the annual $\mathrm{NO}_{\mathrm{x}}-\mathrm{N}$ and $\mathrm{NH}_{\mathrm{y}}-\mathrm{N}$ deposition rates per hectare UAA were averaged for the districts.

Gaseous $\mathrm{NH}_{3}$ emissions are almost entirely caused by agriculture. Thus, the $\mathrm{NH}_{\mathrm{y}}$ deposition on agricultural land originating from $\mathrm{NH}_{3}$ emissions from organic and mineral fertiliser application to the soil represents an internal $\mathrm{N}$ cycle within the soil surface $\mathrm{N}$ budget. In Germany approx. $42 \%$ of total $\mathrm{N}$ volatilisation from agriculture occurs during livestock housing and manure storage, $57 \%$ results from the application of all kinds of fertilisers, and $1 \%$ is released from biogas plants [37]. The $\mathrm{NH}_{3}$ emission attributed to fertiliser application must be subtracted from the gross $\mathrm{NH}_{\mathrm{y}}$ deposition as otherwise it is double counted on the input side and the assessed soil surface surplus would be overestimated. For the spatialised $\mathrm{N}$ soil surface budget it is assumed as a simplification that the $\mathrm{NH}_{\mathrm{y}}$ deposition on the UAA of each district originates exclusively from $\mathrm{NH}_{3}$ emissions within the same district. Thus, for each district the fraction of $\mathrm{NH}_{3}$ emission from fertiliser application from the total agricultural $\mathrm{NH}_{3}$ emissions was calculated. Doing this,
Table $2 \mathbf{N}$ soil surface budget in Germany (averaged over all districts, mean 2015-2017)

\begin{tabular}{|c|c|}
\hline Budget term & $\mathrm{kg} \mathrm{Nha}^{-1} \mathrm{a}^{-1}$ \\
\hline Input total, thereof & 226.5 \\
\hline Mineral fertiliser (inorganic fertiliser) & 103.7 \\
\hline Manure (on-farm production) used as fertiliser & 57.8 \\
\hline Manure import from abroad & 0.9 \\
\hline Digestate from biogas plants & 33.3 \\
\hline Compost, sewage sludge, meat-and-bone meal & 3.2 \\
\hline Biological N fixation & 12.8 \\
\hline Seeds and planting material & 1.3 \\
\hline Atmospheric $\mathrm{NO}_{x}$ deposition on UAA & 4.0 \\
\hline Atmospheric gross $\mathrm{NH}_{3}$ deposition on UAA & 9.5 \\
\hline Output total, thereof & -149.0 \\
\hline Harvest withdrawal of marketed crops & -66.7 \\
\hline $\begin{array}{l}\text { Harvest withdrawal of fodder crops (livestock produc- } \\
\text { tion) }\end{array}$ & -58.3 \\
\hline Harvest withdrawal of energy plants for biogas & -18.6 \\
\hline $\begin{array}{l}\mathrm{NH}_{3} \text { emissions from fertiliser application returned to } \\
\text { UAA }\end{array}$ & -5.4 \\
\hline Budget surplus & 77.4 \\
\hline
\end{tabular}

non-agricultural $\mathrm{NH}_{3}$ emissions were neglected. To calculate the net $\mathrm{NH}_{\mathrm{y}}$ deposition, this fraction was multiplied with the gross $\mathrm{NH}_{\mathrm{y}}$ deposition. The net deposition corresponds to the $\mathrm{NH}_{\mathrm{y}}$ input to the soil surface budget from livestock production and biogas production via the atmosphere. In Table 2 this internal flow is taken into account as ${ }^{\prime} \mathrm{NH}_{3}$ emissions from fertiliser application returned to UAA' as part of the withdrawal.

\section{Harvest withdrawal}

To calculate the $\mathrm{N}$ harvest withdrawal with marketed crops, fodder crops and energy plants, the acreage of the particular crops is multiplied either by the yield per hectare and the $\mathrm{N}$ content in the harvested crop or for field crops without yield data by a fixed withdrawal quantity per hectare [33]. The only by-product considered is straw for bedding in livestock production. No data are available on the thermal use of straw, animal feeding with straw and the harvest and utilisation of other by-products. For soil surface $\mathrm{N}$ balancing it is not necessary to split the harvest withdrawal for utilisation as fodder crops (onfarm use) and energy plants. However, to compare the soil surface $\mathrm{N}$ budget for districts with the German sectoral budget the withdrawal was attributed as follows: all cereals and legumes (harvested as grains), potatoes, sugar beet and rape seed are marketed crops, grassland and green harvested plants are considered as fodder crops. The withdrawal used as energy crops in biogas plants was calculated based on electric work specific substrate mixes 
for each federal state according to KTBL [35] and the fedin electric power from biogas plants. The amounts were subtracted from the harvest withdrawal in marketed and fodder crops.

\section{Territorial status of districts}

Territorial status of the districts refers to 1 January 2016 for the entire time series 1995 to 2017. It comprises 402 regional entities with city federal states (Berlin, Hamburg, and Bremen) treated as districts. For $\mathrm{N}$ budget calculation, the 402 entities were aggregated to 299 socalled "district regions" (map see Additional file 1). The aggregation should avoid methodological errors when calculating the $\mathrm{N}$ budget for urban districts for which the FSS often specifies only little UAA. The FSS applies the "holding location principle", i.e. all cropping acreage and livestock figures are attributed to the district where the holding is registered, wherever the cropland or the livestock housing is actually located. As a result, the true values of acreages and livestock numbers within a district can deviate from the FSS data, distorting the spatial allocation of the $\mathrm{N}$ surpluses to the district's UAA. Additionally, due to the large-scale farming typical for eastern Germany, for a number of districts no UAA or livestock numbers are published in the FSS for reasons of data privacy. These distortions can be at least partially avoided by merging small districts with the larger adjoining district.

\section{Results}

Status and trend of nitrogen input and surplus in Germany At present (mean 2015-2017), the largest input of $104 \mathrm{~kg} \mathrm{~N} \mathrm{ha}^{-1} \mathrm{a}^{-1}$ is made with mineral fertiliser followed by organic fertilisers from livestock and biogas production with nearly $89 \mathrm{~kg} \mathrm{~N} \mathrm{ha}^{-1} \mathrm{a}^{-1}$ (Table 2). Note that the $\mathrm{N}$ budget terms always refer to the UAA, totalled over the districts. $\mathrm{N}$ fixation by legumes contributes

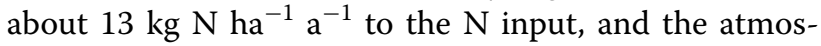
pheric gross deposition amounts to $14 \mathrm{~kg} \mathrm{~N} \mathrm{ha}^{-1} \mathrm{a}^{-1}$. The other inputs are of minor importance with a total of about $8 \mathrm{~kg} \mathrm{~N} \mathrm{ha} \mathrm{k}^{-1} \mathrm{a}^{-1}$. Just under half of the $\mathrm{N}$ withdrawal leaves the agricultural land with marketed field crops (67 kg N ha ${ }^{-1} \mathrm{a}^{-1}$ ), while the remaining $77 \mathrm{~kg} \mathrm{~N}$ $\mathrm{ha}^{-1} \mathrm{a}^{-1}$ is used on-farm as fodder in livestock production or as energy crops. $5 \mathrm{~kg} \mathrm{~N} \mathrm{ha}{ }^{-1} \mathrm{a}^{-1} \mathrm{NH}_{3}$ emissions from fertiliser application, which are returned to the soil with $\mathrm{NH}_{\mathrm{y}}$ deposition are also taken into account into the withdrawal. An input total of around $227 \mathrm{~kg} \mathrm{~N}^{-1}$ $\mathrm{a}^{-1}$ is opposed by a withdrawal from the UAA of around $149 \mathrm{~kg} \mathrm{~N} \mathrm{ha}{ }^{-1} \mathrm{a}^{-1}$, which results in an $\mathrm{N}$ soil surface budget surplus of $77 \mathrm{~kg} \mathrm{~N}^{-1} \mathrm{a}^{-1}$. The NUE in German plant production, thus amounts to 0.658 .

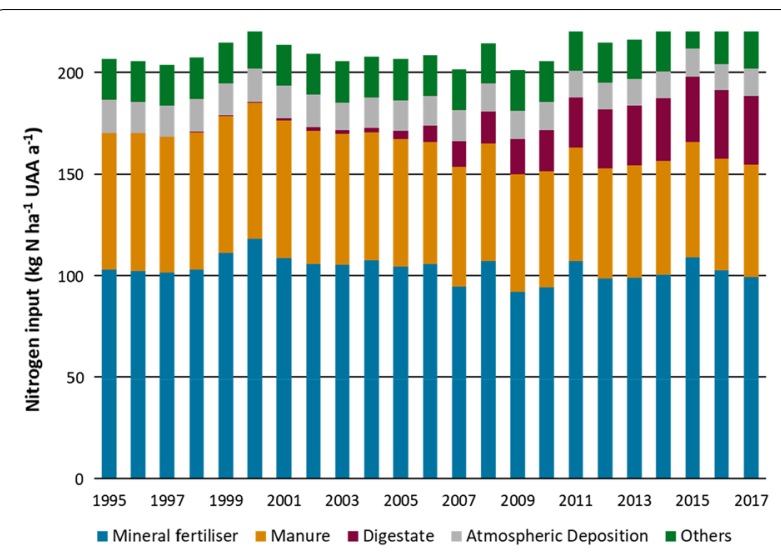

Fig. 1 Input terms of the annual nitrogen soil surface budget of districts aggregated for Germany 1995 to 2017

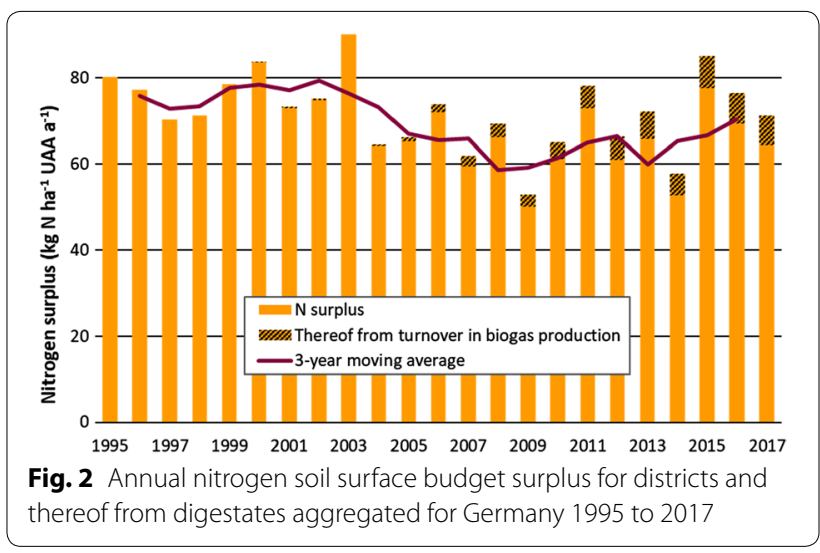

Both, $\mathrm{N}$ input and output are subject to considerable fluctuations over time (Fig. 1). From 1995 to 2017, the N supply in the $\mathrm{N}$ soil surface budget varies between 201 and $232 \mathrm{~kg} \mathrm{~N} \mathrm{ha}^{-1} \mathrm{a}^{-1}$. The fluctuation mainly reflects the annual variation in mineral fertiliser sales volumes, but cannot necessarily be interpreted as actual changes in annual mineral fertiliser application to the UAA. Rather, it can be assumed that farmers and trading companies react to price alterations for mineral fertilisers by building up or reducing stocks. However, the $\mathrm{N}$ budget cannot capture this issue. $\mathrm{N}$ withdrawal with harvested crops (figures not shown) varies significantly more due to weather variability over the period 1995-2017. The span is given by the extremes of the drought year 2003 with an

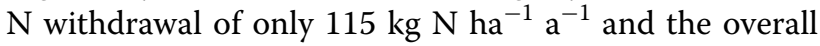
record-yield year 2014 with an $\mathrm{N}$ withdrawal of $162 \mathrm{~kg} \mathrm{~N}$ $\mathrm{ha}^{-1} \mathrm{a}^{-1}$.

The time series of the $\mathrm{N}$ soil surface budget surplus depicts the annual fluctuation of both, the $\mathrm{N}$ input and output, with a maximum of $91 \mathrm{~kg} \mathrm{~N} \mathrm{ha}^{-1} \mathrm{a}^{-1}$ in 2003 and a minimum of $53 \mathrm{~kg} \mathrm{~N} \mathrm{ha}^{-1} \mathrm{a}^{-1}$ in 2009 (Fig. 2). The 
entire period 1995 to 2017 can be separated into two parts. From 1995 up to 2009 a slight downward tendency in the $\mathrm{N}$ budget surplus can be observed, while for the recent period from 2009 onwards no tendency is visible; but none of the regression slopes are statistically significant.

\section{Contribution of biogas production to $\mathrm{N}$ budget surplus}

The share of $\mathrm{N}$ surplus originating from biogas production is proportional to the fraction of energy cropping acreage of the total UAA. Figure 2 shows the increasing share of the $\mathrm{N}$ turnover in biogas production for the $\mathrm{N}$ soil surface budget from the year 2000 onwards. Not accounting for the return of $\mathrm{N}$ with digestate from energy crops in biogas plants to the crop production would lead to a systematic underestimation of the $\mathrm{N}$ soil surface budget surplus.

In 2017, the input to the UAA with digestates contributes $562,900 \mathrm{t} \mathrm{N}$ equivalent to $15 \%$ of the total $\mathrm{N}$ input in crop production, thereof $345,900 \mathrm{t} \mathrm{N}$ are added by energy crops and biowaste and $217,000 \mathrm{t} \mathrm{N}$ by manure used in biogas plants. The share of manure from livestock farming passing a biogas plant before spreading reached $16 \%$ in 2017.

The $\mathrm{N}$ turnover in biogas plants is virtually loss-free, this means no $\mathrm{N}$ withdrawal takes place with biogas production. Theoretically, the amount of 308,000 t N from energy crops (without biowaste) in digestates, assuming an utilisation factor of 0.6 , could replace $184,800 \mathrm{t}$ of mineral $\mathrm{N}$ fertiliser. However, such a decline cannot be observed in the time series of the annual mineral fertiliser input (Fig. 1).

\section{Regional spread of $\mathrm{N}$ budget surplus and NUE}

The $\mathrm{N}$ budget surpluses (mean 2015-2017) of districts spreads over a wide range from $26 \mathrm{~kg} \mathrm{~N} \mathrm{ha}^{-1} \mathrm{a}^{-1}$ to $162 \mathrm{~kg} \mathrm{~N} \mathrm{ha}^{-1} \mathrm{a}^{-1}$ (Fig. 3a), which is more than sixfold between the minimum and the maximum. The NUE of crop production in the districts spans from 0.53 to 0.79 (Fig. 3b). The districts with a high $\mathrm{N}$ surplus show a low NUE of crop production and vice versa (Fig. 3a, b). The highest values of $\mathrm{N}$ surplus (and lowest NUE values) appear in regions with intensive livestock farming such as in north-western Germany and parts of Bavaria. In contrast, the eastern and central districts in Germany, dominated by cash crop farming, are characterised by medium to low $\mathrm{N}$ surplus values.

\section{Change in regional nitrogen budget surplus}

The change in $\mathrm{N}$ soil surface budget surplus from mean 1995-1997 to mean 2015-2017 shows a further widening of the regional spread. The districts with an $\mathrm{N}$ surplus below average show nearly constant (change $\pm 5 \mathrm{~kg} \mathrm{~N}$ $\mathrm{ha}^{-1} \mathrm{a}^{-1}$ ) or decreasing $\mathrm{N}$ surpluses (decline more than $-5 \mathrm{~kg} \mathrm{~N} \mathrm{ha}^{-1} \mathrm{a}^{-1}$ ) over the 23-year period (Fig. 3c). However, in the districts in north-west Germany with high livestock density and therefore a high to very high $\mathrm{N}$ surplus in most cases the $\mathrm{N}$ surplus even increased. In addition, in the districts of Lower Saxony and North Rhine-Westphalia adjacent to the border to the Netherlands, manure imports from the Netherlands lead to an even higher $\mathrm{N}$ surplus. However, increases of $\mathrm{N}$ surplus are partially transferred to the arable farming regions in the eastern part of Lower Saxony, Mecklenburg-Western Pomerania and Saxony-Anhalt via manure export. This means, the huge $\mathrm{N}$ surplus from intensive pig and poultry production in north-west Germany is distributed over a larger area.

\section{Effect of German Fertiliser Ordinance on regional N surplus distribution}

The German Fertiliser Ordinance limits the organic N application to $170 \mathrm{~kg} \mathrm{~N} \mathrm{ha}^{-1} \mathrm{a}^{-1}$ for the individual farms, which is approximately equivalent to a livestock density of 1.8 livestock units (LU) per hectare on district average. Thus, for districts with a livestock density of $>1.8$ $\mathrm{LU} \mathrm{ha}{ }^{-1}$ this regulation forces the farmers to export their excess manure $>170 \mathrm{~kg} \mathrm{~N} \mathrm{ha}^{-1} \mathrm{a}^{-1}$ to other regions with capacity to uptake additional organic fertiliser $\mathrm{N}$ under the restrictions as given by the German Fertiliser Ordinance. Figure 4 illustrates that the $\mathrm{N}$ soil surface budget surplus (mean 2015-2017) is closely correlated to the livestock density for all districts up to $1.8 \mathrm{LU} \mathrm{ha}^{-1}$ with an increase of $\mathrm{N}$ surplus by nearly $60 \mathrm{~kg} \mathrm{~N} \mathrm{ha}^{-1} \mathrm{a}^{-1}$ for an increase in livestock density by one LU ha ${ }^{-1}$ UAA (grey symbols in Fig. 4). According to the nutrient reports of the states North Rhine-Westphalia and Lower Saxony, in 11 districts (with $>1.8 \mathrm{LU} \mathrm{ha}^{-1}$ ) the net manure transfer reduces the $\mathrm{N}$ surplus by more than $-10 \mathrm{~kg} \mathrm{~N} \mathrm{ha}^{-1} \mathrm{a}^{-1}$ (mean 2015-2017), the maximum reported reduction is $-99 \mathrm{~kg} \mathrm{~N} \mathrm{ha}^{-1} \mathrm{a}^{-1}$ for the district Vechta. For these 11 districts the $\mathrm{N}$ surplus would hypothetically grow by nearly $60 \mathrm{~kg} \mathrm{~N} \mathrm{ha}^{-1} \mathrm{a}^{-1}$ per LU ha ${ }^{-1}$ and reach up to nearly $240 \mathrm{~kg} \mathrm{~N} \mathrm{ha}^{-1} \mathrm{a}^{-1}$ (red symbols) without the limitation of organic $\mathrm{N}$ fertilising. Thus, the threshold of $170 \mathrm{~kg} \mathrm{~N}$ $\mathrm{ha}^{-1} \mathrm{a}^{-1}$ organic $\mathrm{N}$ application set by the Fertiliser Ordinance forces the farms to discount a part of their organic $\mathrm{N}$ by manure transfer and therefore confines the $\mathrm{N}$ surplus increase to a moderate rise in these districts (blue symbols). Due to the small number of districts with $>1.8$ $\mathrm{LU} \mathrm{ha}{ }^{-1}$ these results should be interpreted cautious. Changes in $\mathrm{N}$ soil surface surplus might be driven too by other political measures and local water protection actions in the districts and might also be partly caused by market-driven changes of the agricultural structure. 
a

Nitrogen surplus, mean 2015-2017

( $k g \mathrm{~N} \mathrm{ha}^{-1}$ UAA a ${ }^{-1}$ )

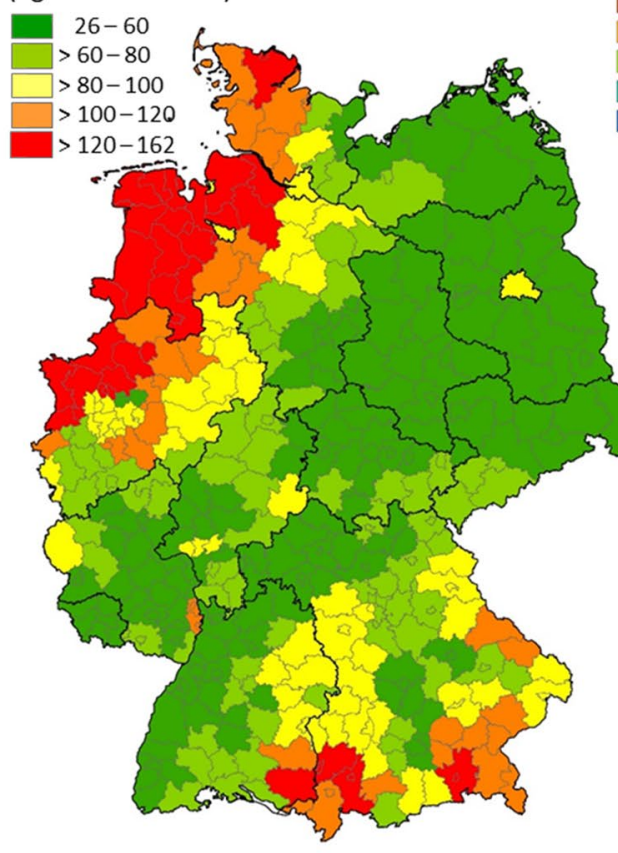

C

Nitrogen surplus, change $1995 / 97$ to $2015 / 17$ ( $k g \mathrm{Nha}^{-1}$ UAA a ${ }^{-1}$ )

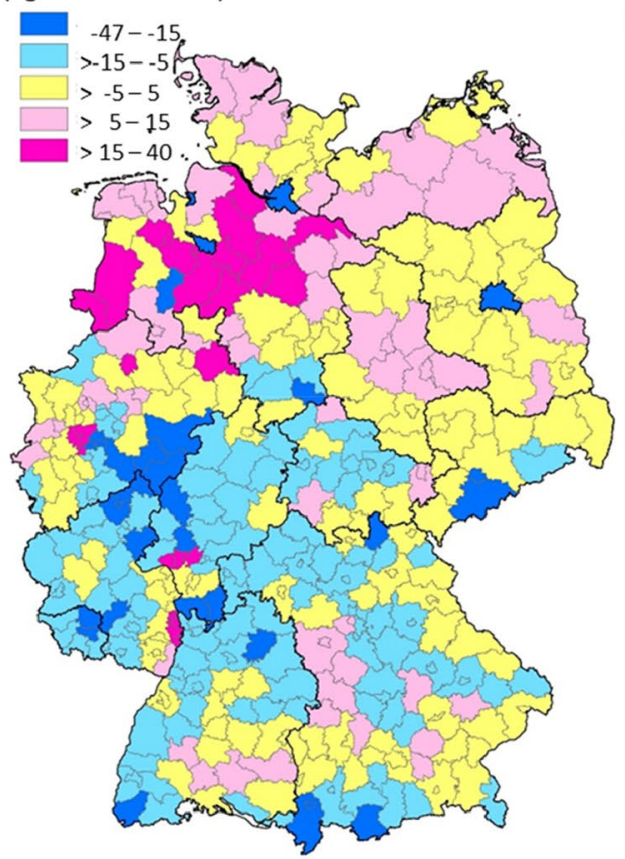

b
Nitrogen use efficiency (NUE), mean 2015-2017

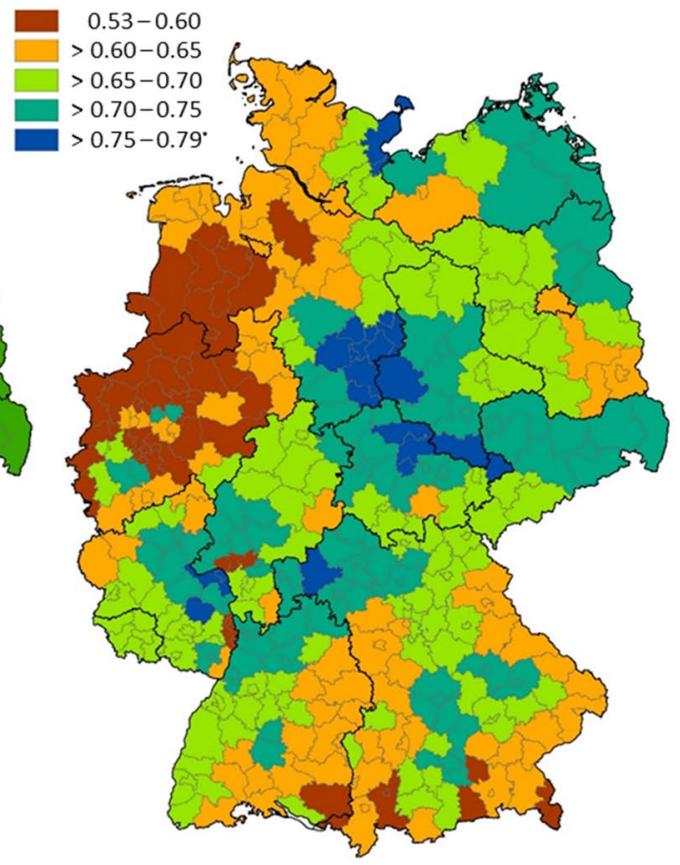

d

Nitrogen surplus change due to manure transfer and import from the Netherlands, mean 2015-2017

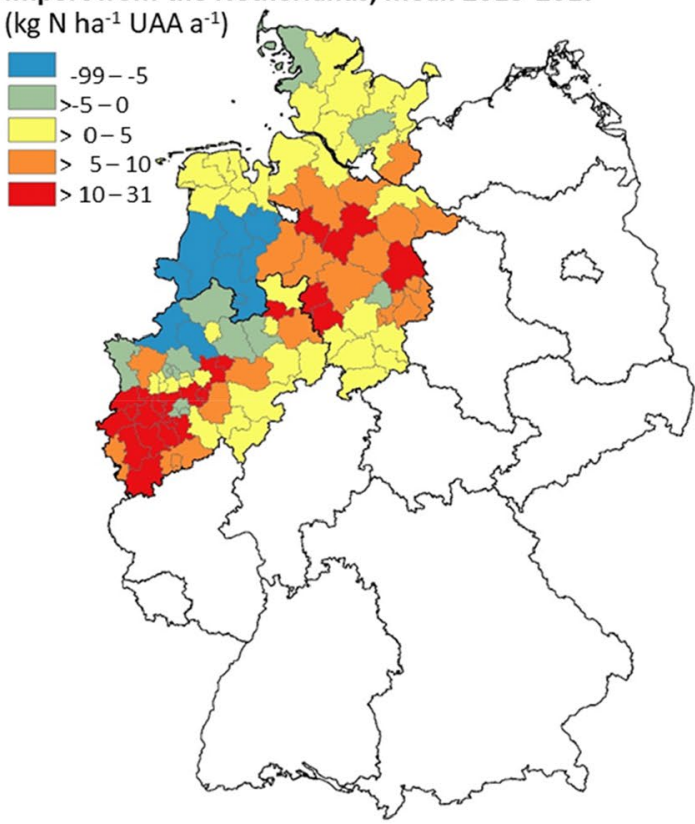

Fig. 3 Nitrogen budget surplus of nitrogen soil surface budgets of districts in Germany, mean 2015-2017 (a), and nitrogen use efficiency, mean 2015-2017 (b), change in N surplus from 1995-1997 to 2015-2017 per utilised agricultural area (UAA) (c), and nitrogen surplus change due to manure transfer and import from the Netherlands, mean 2015-2017 (d) 


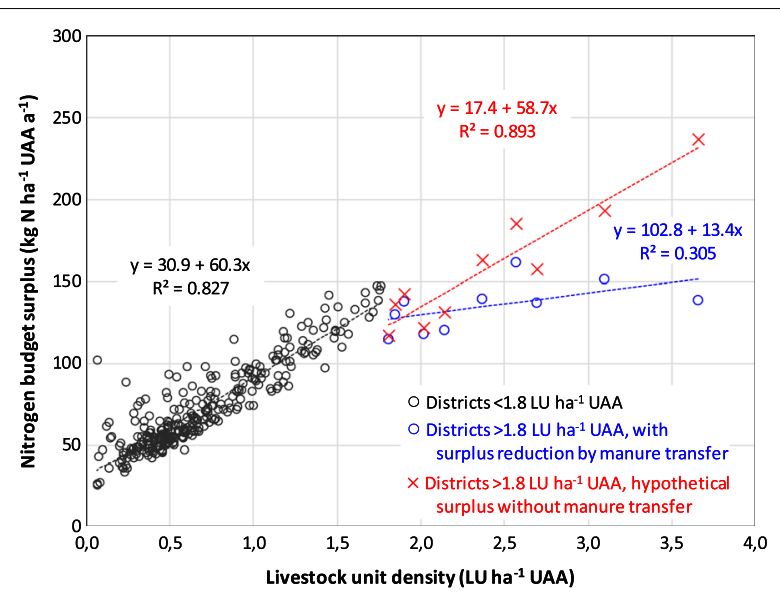

Fig. 4 Nitrogen soil surface budget surplus of districts in Germany as a function of livestock unit (LU) density (mean 2015-2017) and the effect of $\mathrm{N}$ surplus reduction by manure transfer (withdrawal) for the districts with more than 1.8 livestock units per hectare utilised agricultural area (UAA)

\section{Discussion and conclusions}

Several published results on the $\mathrm{N}$ soil budget surplus in Germany agree well with the $\mathrm{N}$ surplus presented here. Leip et al. [11] calculated an $\mathrm{N}$ surplus of $76.1 \mathrm{~kg} \mathrm{~N}^{-1}$ UAA for Germany based on the agri-economic model CAPRI (years 2001-2003), while our figure for these years is $79.8 \mathrm{~kg} \mathrm{~N}^{-1}$ UAA. With a coupling of several high resolution models of $\mathrm{N}$ fluxes in Europe, Leip et al. [21] further estimated an $\mathrm{N}$ surplus for agricultural soils of $89.8 \mathrm{~kg} \mathrm{~N} \mathrm{ha}^{-1}$ UAA (year 2002) for Germany. Among other things, the difference of $10 \mathrm{~kg} \mathrm{~N} \mathrm{ha}^{-1}$ UAA to our result can be attributed to the fact that essential quantities of the $\mathrm{N}$ soil budget such as $\mathrm{N}$ mineral fertilisation and crop yield have also been model-generated by Leip et al. [21]. In contrast, we used available statistical data, as did Leip et al. [11] in the CAPRI-based approach, where a country is treated as an aggregated (single) farm. The agricultural soil surface $\mathrm{N}$ surplus of $71.9 \mathrm{~kg} \mathrm{~N}^{-1}$ hAA for Germany (year 1997) by Campling et al. [23] is almost identical to the corresponding value of $72.9 \mathrm{~kg} \mathrm{~N}^{-1}$ UAA (mean 1996-1998) from our study. Our values of the $\mathrm{N}$ soil surface budgets summed up for the districts match also very well with the figures of the national $\mathrm{N}$ budget which is published annually by the Federal Ministry of Agriculture [37] and which serves as reference values for spatialised $\mathrm{N}$ budgets in Germany. Averaged over the time period 1995-2017 the difference is less than $1 \mathrm{~kg}$ $\mathrm{N} \mathrm{ha}{ }^{-1} \mathrm{a}^{-1}$ UAA, due to a harmonisation of the underlying calculation methods between the two responsible working groups.

Overall, the long-time series of the $\mathrm{N}$ district soil surface surplus in Germany presented here forms a reliable basis for further interpretation, mainly with regard to the following questions: (a) How has the $\mathrm{N}$ surplus developed over time, both in Germany as a whole and regionally? Does the $\mathrm{N}$ surplus show a reaction to agri-environmental policies and actions? (b) In which districts are the highest $\mathrm{N}$ surpluses to be found ("hot spots")? How pronounced are the regional differences?

Obviously the time series of Germany's $\mathrm{N}$ soil surface budget surplus show no decline in the past ten years (Fig. 1). Apparently, the agri-environmental action programmes over the last twenty years were not sufficient to reduce the altogether high and regionally excessive $\mathrm{N}$ surpluses in German agriculture. That was judged by the EU Court of Justice on 21 June 2018 (case C-543/16) declaring that the Federal Republic of Germany failed to fulfil its obligations under Council Directive 91/676/EEC concerning the protection of ground water against pollution caused by nitrates and high $\mathrm{N}$ loads into North Sea and Baltic Sea from agricultural sources as documented in the first Nitrate Report published in 1996 and every Nitrate Report published since then thereafter.

This development is partly caused by the expansion of biogas production, because an increasing amount of $\mathrm{N}$ is retained within the agricultural cycle, as the $\mathrm{N}$ in harvested energy crops returns (almost) completely to the UAA with the digestates and less $\mathrm{N}$ leaves the agricultural sector in the form of marketed crops. Additionally, since the fermentation of manure in (gas-tight) biogas plants causes lower gaseous $\mathrm{N}$ losses compared to storage in uncovered slurry tanks, more $\mathrm{N}$ is applied with the digestate compared to the equivalent amount of manure and thus the $\mathrm{N}$ surplus tends to increase. These effects can be determined only when biogas production is included in the $\mathrm{N}$ budget scheme.

The development of the $\mathrm{N}$ soil surface surplus in the districts over 20 years shows a distinct spatial disproportionation. In the majority of the districts which had a low initial N surplus in 1995-1997, the values have decreased, while those districts with a high initial $\mathrm{N}$ surplus show a clear further increase (Fig. 3c). We assume that the spatial disproportionation is a consequence of the specialisation of German agriculture: animal husbandry, in particular pork and poultry production, has been concentrated in a few regions. Contrasting, livestock production is abandoned in large parts of Germany and farmers there mainly practise arable farming. Nevertheless, comparing the changes 1995-1997 to 2015-2017 of the $\mathrm{N}$ soil surface surplus and NUE, respectively, with the changes of the livestock density in the districts no significant correlation can be observed $\left(R^{2}=0.06\right.$ and 0.07 , respectively). The exclusion of manure transfers, however, lead to a higher correlation between the change of livestock densities and the change of $\mathrm{N}$ surpluses 
$1995-1997$ to $2015-2017\left(R^{2}=0.47\right)$. This lead us to the conclusion, that the impact of livestock density changes on the $\mathrm{N}$ soil surface surplus on the district level is largely offset by manure transfers.

Given this situation, the most noticeable effect of the Fertiliser Ordinance, which implemented Council Directive 91/676/EEC in Germany (first in 1996), appears to be that the application of manure was limited to $170 \mathrm{~kg} \mathrm{~N}$ $\mathrm{ha}^{-1}$ UAA. As a result, from the hot spot districts significant quantities of manure are transferred to adjacent regions with low livestock density which still have capacity for additional $\mathrm{N}$ input in their $\mathrm{N}$ budget, given the restrictions by the German Fertiliser Ordinance, as shown by Fig. 4 .

Compared to the $\mathrm{N}$ soil surface budget surplus of major European countries (Fig. 5), our results show the same temporal development as most the $\mathrm{N}$ soil surface budget surplus except for the United Kingdom. Since these data sets are based on different, country-specific methodologies [38] a comparison between the results is only viable with limitations, it is recognisable, that the results for Germany do not deviate strongly from those of other European countries. However, it strongly deviates from the Eurostat data set for Germany (data not shown), which shows a decline since 1995, that partly can be explained by not including biogas production into this data set.
Irrespective of the evaluation that the $\mathrm{N}$ budget provides robust and meaningful results, some weaknesses and options for improvement of the $\mathrm{N}$ budget approach presented here are also addressed in the following.

1. The fluctuations in the $\mathrm{N}$ input and output and also in the budget surplus impair the informative value of the figures for individual years. Thus, moving averages (three-yearly or longer) of budget values should always be used as the basis for evaluation and trend analysis of the $\mathrm{N}$ surplus.

2. The surplus of the $\mathrm{N}$ soil surface budget is a proxy value to characterise the nitrate groundwater pollution potential averaged over the entire UAA of a district, i.e. over all soil types and climate zones, types of farming (cash crop farming, livestock farming), crop types, and cultivation methods (conventional, organic) $[39,40]$. The results are therefore only suitable for large-scale comparisons and do not permit any statements with a higher spatial resolution (within the districts). This leads to an average value that probably underestimates the actual $\mathrm{N}$ surplus for intensively managed UAA within a district, but overestimates it for extensively used areas. As an example, the districts along the Upper Rhine Plain in Baden-Wurttemberg can be cited, each comprising in almost equal proportions cash crop farms in

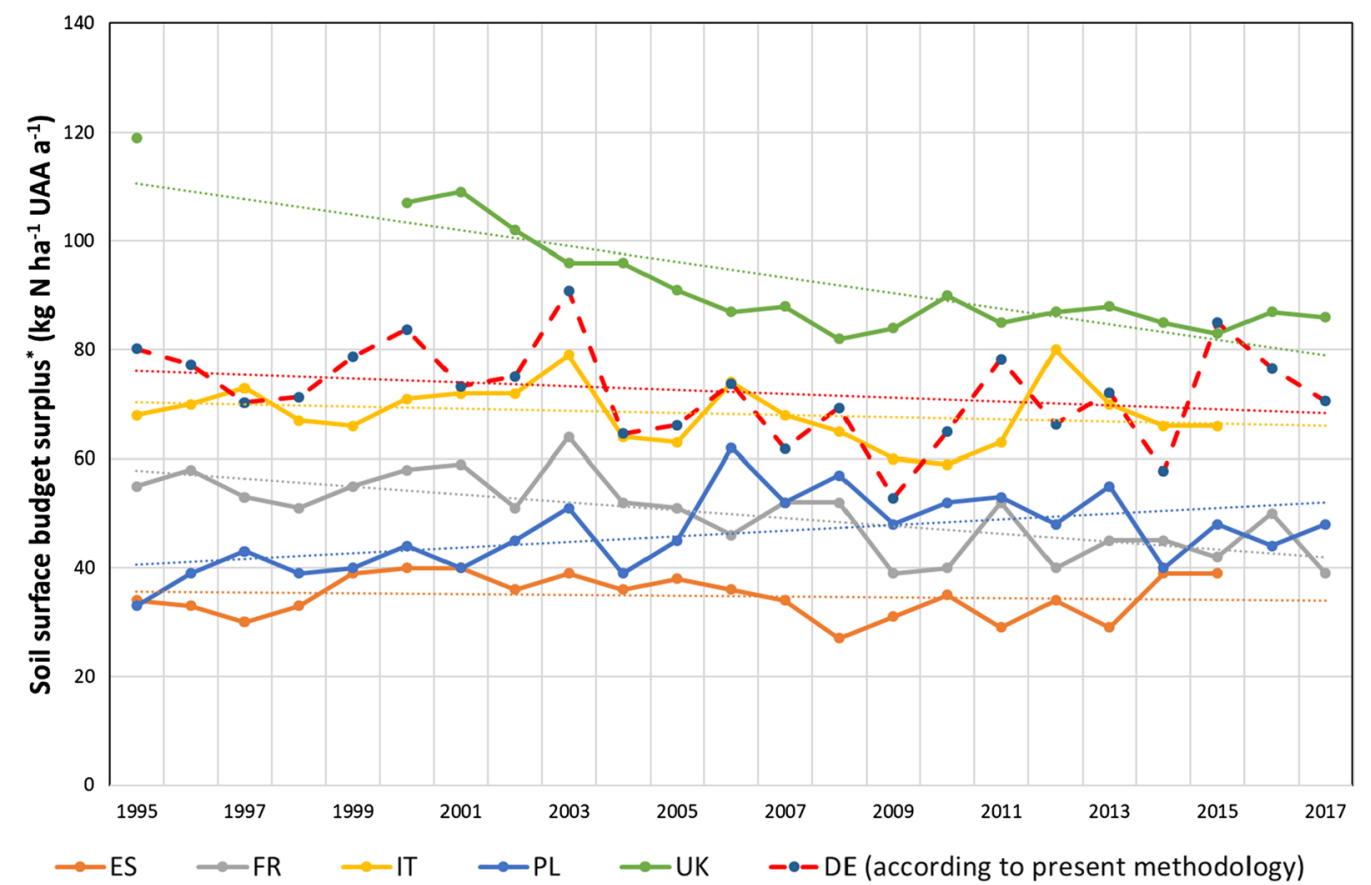

Fig. 5 Comparison of the N soil surface budget surplus (1995 to 2017) of selected European countries (Spain, France, Italy, Poland and United Kingdom) according to Eurostat [38] to the N soil surface budget surplus Germany according to present methodology 
the Upper Rhine Plain and cattle farms in the Black Forest. These problems can partly be solved by calculating future $\mathrm{N}$ surpluses separately for arable land, permanent crops and grassland.

3. The district $N$ surplus refers to spatial units of very different size. In 2016, the UAA in the districts in Germany (district-free cities not included) ranged from 7000 ha UAA (district Sonneberg) to about 341,000 ha UAA (district Börde). Thus, the spatial representativeness of the individual $\mathrm{N}$ surplus figures span over a large range.

4. All federal states offer agri-environmental programmes which stipulate a limitation of $\mathrm{N}$ fertilisation and therefore reduce the $\mathrm{N}$ surplus of the included UAA. However, the $\mathrm{N}$ fertilisation cap varies substantially between the federal states and furthermore the programmes are subscribed to varying degrees in the districts. These factors modify the district $\mathrm{N}$ surpluses, but are not reflected in the approach for calculating the $\mathrm{N}$ mineral fertilising for the districts (Eq. 4).

5. Organic farms do not use mineral fertilisers and therefore have typically a lower $\mathrm{N}$ budget surplus [41, 42]. The proportion of organically managed UAA varies considerably between districts. This factor has not yet been taken into account in the $\mathrm{N}$ budget approach up to date; to improve the surplus results, the $\mathrm{N}$ soil budget for conventionally and organically managed UAA should be calculated separately.

In Germany, mineral fertiliser sales statistics are available at the state level. The approach to derive the regional mineral fertilising amounts remains the biggest methodological challenge and at the same time the most sensitive factor for the district $\mathrm{N}$ budget surpluses. As long as no detailed representative statistical data on mineral fertilising at farm level are available, we consider that the method applied here is a viable approach. Other publications presenting spatialised $\mathrm{N}$ soil surface budgets used different approaches, e.g. Özbek and Leip [18] employed regional mineral fertiliser sales statistics for 26 NUTS 2-regions in Turkey as well as Eriksson et al. [15] for two river basins in Poland. Grizzetti et al. [16] intersected culture-, year- and country-specific mineral fertiliser application rates as published by the International Fertiliser Association (IFA) with CORINE Land Cover maps to derive specific mineral fertiliser application rates for NUTS 2-regions of 15 EU member states. Lassaletta et al. [19] applied a similar approach for the calculation of spatialised $\mathrm{N}$ soil surface budgets in the Ebro river basin in Spain. Gamer et al. [43] used mineral fertiliser sales data from the German Farm Accountancy Data Network
(FADN) to calculate spatialised N, P, and K balances in Baden-Württemberg.

Since 2014 district-level data on the transfer of farm fertilisers are available in the nutrient reports of four federal states in Germany [44-46]. However, there is a lack of data on the distribution of the manure released among the districts in the federal states without nutrient reports. To improve the transparency of the manure transfer, appropriate data should be collected in the federal states concerned. The next complete FSS will be conducted in 2020. Compared to earlier surveys, it will provide more detailed information on the storage and application of farm manure, bedding materials, organic fertiliser transfer, and other items. We expect that the calculation of spatialised $\mathrm{N}$ soil surface budgets can be further developed and improved on the basis of these data and considering the weak points listed above.

Uncertainty and sensitivity analysis as well as the evaluation of measures to reduce $\mathrm{N}$ budget surpluses will be published in two separate articles.

\section{Supplementary information}

Supplementary information accompanies this paper at https://doi. org/10.1186/s12302-020-00382-x.

Additional file 1. Nitrogen soil surface budgets for districts in Germany 1995 to 2017.

\section{Abbreviations}

IF: Fertiliser input factor; EU: European Union; FSS: Farm structure survey; LU: Livestock unit; N: Nitrogen; $\mathrm{NH}_{3}$ : Ammonia; NUE: Nitrogen use efficiency; NUTS: Nomenclature des unités territoriales statistiques; OECD: Organisation for Economic Co-operation and Development; PINETI: Pollutant input and ecosystem impact; UAA: Utilised agricultural area; UF: Utilisation factor.

\section{Acknowledgements}

Not applicable.

\section{Authors' contributions}

$U H, M B, A U, L B$, and $G W$ designed and coordinated this research. $U H, L B$, and $M B$ drafted the manuscript. LK participated in the development of the underlying methodology. All authors read and approved the final manuscript.

\section{Funding}

The project underlying this publication was coordinated and funded by the German Environment Agency in the framework of the environment research plan of the Federal Ministry for the Environment, Nature Conservation and Nuclear Safety (project no. 371443202 0). Open access funding provided by Projekt DEAL.

\section{Availability of data and materials}

The datasets used and/or analysed during the current study are available from the corresponding author on request.

Ethics approval and consent to participate Not applicable.

Consent for publication

Not applicable. 


\section{Competing interests}

We declare that no conflicts of interest exist in the submission of this manuscript.

\section{Author details}

${ }^{1}$ Institute for Landscape Ecology and Resources Management, Research Centre for BioSystems, Land Use and Nutrition (iFZ), Justus Liebig University Giessen, Heinrich-Buff-Ring 26, 35392 Giessen, Germany. ${ }^{2}$ Centre for International Development and Environmental Research (ZEU), Justus Liebig University Giessen, Senckenbergstr. 3, 35390 Giessen, Germany. ${ }^{3}$ Federal Environment Agency Germany, Wörlitzer Platz 1, 06844 Dessau-Rosslau, Germany.

\section{Received: 9 November 2019 Accepted: 24 July 2020}

\section{Published online: 14 August 2020}

\section{References}

1. Galloway J, Aber JD, Erisman JW et al (2003) The nitrogen cascade. Bioscience 53:341-356

2. Erisman JW, Sutton MA, Galloway J et al (2008) How a century of ammonia synthesis changed the world. Nature Geosci 1:636-639. https://doi. org/10.1038/ngeo325

3. Fowler D, Coyle M, Skiba U et al (2013) The global nitrogen cycle in the twenty-first century. Philos Trans R Soc Lond B Biol Sci 368:20130164. https://doi.org/10.1098/rstb.2013.0164

4. United Nations Environment Programme (2007) Division of Technology, Industry, and Economics (UNEP), The Woods Hole Research Center Reactive nitrogen in the environment. Too much or too little of a good thing, UNEP/Earthprint, Paris, Falmouth

5. Oenema O, Kros H, de Vries W (2003) Approaches and uncertainties in nutrient budgets: implications for nutrient management and environmental policies. Eur J Agron 20:3-16. https://doi.org/10.1016/S1161 -0301(03)00067-4

6. Commission of the European Communities (2006) Development of agrienvironmental indicators for monitoring the integration of environmental concerns into the common agricultural policy. Communication from the Commission to the Council and the European Parliament. COM(2006) 508 final. https://eur-lex.europa.eu/LexUriServ/LexUriServ.do?uri=COM:2 006:0508:FIN:EN:PDF. Accessed 01 Oct 2019

7. European Environment Agency (EEA) (2005) Agriculture and environment in EU-15-the IRENA indicator report. EEA report 6/2005, Copenhagen

8. de Vries W, Leip A, Reinds GJ et al (2011) Geographical variation in terrestrial nitrogen budgets across Europe. Chapter 15. In: Sutton M, Howard C, Erisman JW, Billen G et al (eds) The European Nitrogen Assessment. Cambridge University Press, Cambridge, pp 317-344

9. Hansen B, Thorling L, Dalgaard T et al (2011) Trend reversal of nitrate in Danish groundwater-a reflection of agricultural practices and nitrogen surpluses since 1950. Environ Sci Technol 45:228-234. https://doi. org/10.1021/es102334u

10. European Commission Directorate E: Sectoral and regional statistics Unit E-1: Agriculture and fisheries, Eurostat (2013) Nutrient Budgets. EU-27, Norway, Switzerland. Methodology and Handbook Eurostat/OECD: Version 1.02, Luxembourg City

11. Leip A, Britz W, Weiss F et al (2011) Farm, land, and soil nitrogen budgets for agriculture in Europe calculated with CAPRI. Environ Pollut 159:32433253. https://doi.org/10.1016/j.envpol.2011.01.040

12. Organisation for Economic Co-operation and Development (OECD) (2001) Environmental Indicators for Agriculture. Volume 3, Paris

13. Organisation for Economic Co-operation and Development (OECD), Eurostat (2007) Gross Nitrogen Balances Handbook. Paris, Luxembourg City

14. Conant RT, Berdanier AB, Grace PR (2013) Patterns and trends in nitrogen use and nitrogen recovery efficiency in world agriculture. Global Biogeochem Cycles 27:558-566. https://doi.org/10.1002/gbc.20053

15. Eriksson H, Pastuszak M, Löfgren S et al (2007) Nitrogen budgets of the Polish agriculture 1960-2000: implications for riverine nitrogen loads to the Baltic Sea from transitional countries. Biogeochemistry 85:153-168. https://doi.org/10.1007/s10533-007-9126-y
16. Grizzetti B, Bouraoui F, Aloe A (2007) Spatialised European Nutrient Balance. Office for Official Publications of the European Communities, Luxemburg

17. Wang X, Feng A, Wang Q et al (2014) Spatial variability of the nutrient balance and related NPSP risk analysis for agro-ecosystems in China in 2010. Agr Ecosyst Environ 193:42-52. https://doi.org/10.1016/j. agee.2014.04.027

18. Özbek FŞ, Leip A (2015) Estimating the gross nitrogen budget under soil nitrogen stock changes: a case study for Turkey. Agr Ecosyst Environ 205:48-56. https://doi.org/10.1016/j.agee.2015.03.008

19. Lassaletta L, Romero E, Billen $G$ et al (2012) Spatialized $N$ budgets in a large agricultural Mediterranean watershed: high loading and low transfer. Biogeosciences 9:57-70. https://doi.org/10.5194/bg-9-57-2012

20. Bach M, Frede H-G (2005) Assessment of Agricultural Nitrogen Balances for Municipalities-Example Baden-Wuerttemberg (Germany). https://www.google.de/url?sa $=t \& r c t=j \& q=\& e s r c=s \&$ source $=$ web $\& c d=3 \& v e d=2$ ahUKEwi_zdHV-fvkAhXEIFwKHb|6BPoQFjACegQIA BAC\&url=http\%3A\%2F\%2Fforum.eionet.europa.eu\%2Fnrc-eionetfreshwater\%2Flibrary\%2Fother-workshops\%2Fagri-water_meeting\%2Fm unicipalitiespdf\%2Fdownload\%2Fen\%2F1\%2FPaper_Bach_Frede_N_Balances_Municipalities.pdf\&usg=AOvVaw0Gpozur2rWG5Wm41 kqhHhi. Accessed 01 Oct 2019

21. Leip A, Achermann B, Billen G et al (2011) Integrating nitrogen fluxes at the European scale. In: Sutton M, Howard C, Erisman JW, Billen G et al (eds) The European Nitrogen Assessment. Cambridge University Press, Cambridge UK, pp 345-376

22. Wendland F, Albert $\mathrm{H}$, Bach M et al (eds) (1993) Atlas zum Nitratstrom in der Bundesrepublik Deutschland. Rasterkarten zu geowissenschaftlichen Grundlagen, Stickstoffbilanzgrößen und Modellergebnissen. Springer, Berlin

23. Campling P, Terres JM, Vande Walle S et al (2005) Estimation of nitrogen balances from agriculture for EU-15. Spatialisation of estimates to river basins using the CORINE Land Cover. Physics and Chemistry of the Earth, Parts A/B/C 30:25-34. https://doi.org/10.1016/j.pce.2004.08.014

24. Velthof GL, Oudendag D, Witzke HP et al (2009) Integrated assessment of nitrogen losses from agriculture in EU-27 using MITERRA-EUROPE. J Environ Qual 38:402-417. https://doi.org/10.2134/jeq2008.0108

25. Bouraoui F, Grizzetti B (2014) Modelling mitigation options to reduce diffuse nitrogen water pollution from agriculture. Sci Total Environ 468-469:1267-1277. https://doi.org/10.1016/j.scitotenv.2013.07.066

26. Yang JR, Jong RD, Drury CF et al. (2006) Development of a Canadian Agricultural Nitrogen Budget (CANB v2.0) model and the evaluation of various policy scenarios. Can J Soil Sci. pp 153-165

27. Howarth R, Swaney D, Billen G et al (2012) Nitrogen fluxes from the landscape are controlled by net anthropogenic nitrogen inputs and by climate. Front Ecol Environ 10:37-43. https://doi.org/10.1890/100178

28. Statistisches Bundesamt (Destatis) (2019) Sustainable Development in Germany. Indicator Report 2018. Wiesbaden

29. Venohr M, Hirt U, Hofmann J et al (2011) Modelling of Nutrient Emissions in River Systems-MONERIS-Methods and Background. Int Rev Hydrobiol 96:435-483. https://doi.org/10.1002/iroh.201111331

30. Fuchs S, Kaiser M, Kiemle L et al (2017) Modeling of Regionalized Emissions (MoRE) into Water Bodies: an Open-Source River Basin Management System. Water 9:239. https://doi.org/10.3390/w9040239

31. Fuchs S, Weber T, Wander R et al. (2017) Effizienz von Maßnahmen zur Reduktion von Stoffeinträgen. Endbericht. UBA-Texte 5/2017, Dessau-Roßlau

32. Kreins P, Gömann H, Herrmann S et al (2007) Integrated Agricultural and Hydrological Modeling within an Intensive Livestock Region. In: Messner F, Ring I, Erickson JD (eds) Ecological economics of sustainable watershed management, vol 7. Elsevier JAI. Amsterdam, Oxford, pp 113-142

33. Düngeverordnung (2017) Verordnung über die Anwendung von Düngemitteln, Bodenhilfsstoffen, Kultursubstraten und Pflanzenhilfsmitteln nach den Grundsätzen der guten fachlichen Praxis beim Düngen (Düngeverordnung - DüV). Bundesgesetzblatt Teil 1:1305-1345

34. Rösemann C, Haenel HD, Dämmgen U et al. (2019) Berechnung von gas- und partikelförmigen Emissionen aus der deutschen Landwirtschaft 1990-2017. Bericht zu Methoden und Daten (RMD) Berichterstattung 2019. Thünen Report 67, Braunschweig

35. Kuratorium für Technik und Bauwesen in der Landwirtschaft (2016) Gesonderte Aufbereitung der Daten zum spezifischen Stickstoffeintrag in 
landwirtschaftliche Biogasanlagen aus den Aktivitätsdaten Biogas für den Nationalen Inventarbericht

36. Schaap M, Hendriks C, Kranenburg R et al. (2018) PINETI-3: Modellierung atmosphärischer Stoffeinträge von 2000 bis 2015 zur Bewertung der ökosystem-spezifischen Gefährdung von Biodiversität durch Luftschadstoffe in Deutschland. Abschlussbericht. UBA-Texte 79/2018, Dessau-Roßlau

37. Bundesministerium für Ernährung und Landwirtschaft (2019) Statistischer Monatsbericht des Bundesministeriums für Landwirtschaft und Ernährung, Kapitel A. Landwirtschaft. Tabellen zu Nährstoffbilanzen und Düngemittel. https://www.bmel-statistik.de/landwirtschaft/statistischermonatsbericht-des-bmel-kapitel-a-landwirtschaft/

38. Eurostat (2020) Gross nutrient balance [aei_pr_gnb]. https://appsso.euros tat.ec.europa.eu/nui/show.do?dataset=aei_pr_gnb\&lang=en

39. Grizzetti B, Bouraoui F, Billen G et al (2011) Nitrogen as a threat to European water quality. In: Sutton M, Howard C, Erisman JW, Billen G et al (eds) The European Nitrogen Assessment. Cambridge University Press, Cambridge, pp 379-404

40. Knoll L, Breuer L, Bach M (2019) Large scale prediction of groundwater nitrate concentrations from spatial data using machine learning. Sci Total Environ 668:1317-1327. https://doi.org/10.1016/j.scitotenv.2019.03.045

41. Küstermann B, Christen O, Hülsbergen K-J (2010) Modelling nitrogen cycles of farming systems as basis of site- and farm-specific nitrogen management. Agr Ecosyst Environ 135:70-80. https://doi.org/10.1016/j. agee.2009.08.014
42. Lin H-C, Huber JA, Gerl G et al (2016) Nitrogen balances and nitrogen-use efficiency of different organic and conventional farming systems. Nutr Cycl Agroecosyst 105:1-23. https://doi.org/10.1007/s10705-016-9770-5

43. Gamer W, Bahrs E (2010) Bilanzen von potenziell umweltbelastenden Nährstoffen (N, P, K und S) der Landwirtschaft in Baden-Württemberg. Forschungsauftrag des Ministeriums für Ernährung und Ländlichen Raum, Baden-Württemberg. Stuttgart-Hohenheim

44. Landwirtschaftskammer Niedersachsen (2019) Nährstoffbericht für Niedersachsen 2017/2018. Oldenburg

45. Landwirtschaftskammer Nordrhein-Westfalen (2018) Nährstoffbericht 2017 über Wirtschaftsdünger und andere organische Dünger für Nordrhein-Westfalen. Münster (Westf)

46. Taube F, Hennecke A, Albrecht E, Reinsch T, Kluß C (2015) Nährstoffbericht des Landes Schleswig-Holstein im Auftrag des Ministeriums für Energiewende, Landwirtschaft. Umwelt und ländliche Räume SchleswigHolstein, Kiel

\section{Publisher's Note}

Springer Nature remains neutral with regard to jurisdictional claims in published maps and institutional affiliations.

\section{Submit your manuscript to a SpringerOpen ${ }^{\circ}$ journal and benefit from:}

- Convenient online submission

- Rigorous peer review

- Open access: articles freely available online

- High visibility within the field

- Retaining the copyright to your article

Submit your next manuscript at $\gg$ springeropen.com 